\title{
An analysis of tax knowledge base system usage behaviour at KPP Madya South Jakarta I
}

\author{
Nur'Aini Setyaningrum ${ }^{1}$ and Milla Sepliana Setyowati ${ }^{2 *}$ \\ ${ }^{1}$ Department of Fiscal Administrative Sciences, Faculty of Administrative Science, Universitas \\ Indonesia, Depok, 16424, Indonesia \\ ${ }^{2}$ Department of Fiscal Administrative Sciences, Faculty of Administrative Science, Universitas \\ Indonesia, Depok, 16424, Indonesia
}

\begin{abstract}
The Directorate General of Taxation has established an online repository called Tax Knowledge Base or TKB. TKB has been widely recognized and used by tax authorities, albeit not maximally. This study used a quantitative descriptive method to analyse constructs of the Unified Theory of Acceptance and Use of Technology to specifically figure out TKB use at KPP Madya South Jakarta I with a sample size of 88. A significant effect was demonstrated by Performance Expectancy on Behavioural Intention, Facilitating Condition and Behavioural Intention to Use Behaviour. Insignificance was apparent in the effect of Effort Expectancy and Social Influence on Use Behaviour. This study recommends that the Directorate General of Taxation should require tax authorities to use TKB on a daily basis.
\end{abstract}

\section{Introduction}

Tax as the main source of state revenue has a significant role to succeeded the Sustainable Development Goals (SDGs). 17 SGD pillars can be realized with adequate funding, which of course is mostly derived from taxes, especially the pillars that associated with no poverty, zero hunger, good health and well-being, quality education, decent work and economic growth, and also industry, innovation, and infrastructure. As the main sources of state revenues, especially in Indonesia, are needed to renew tax administration with the development of information technology, in order to increase the effective and efficient of DGT in carrying out tax collection.

The Directorate General of Taxation (DJP) has made an upgrade of taxation administration through information technology development. This information technology has increased the DJP's effectiveness and efficiency in collecting taxes. The onset of DJP's use of technology was marked in 1990 by the adoption of NPCS (Network Processing Control System) for tax payment supervision and evaluation. To create a Tax Informatin System that is universally accepted by all tax authorities is a challenge to the DJP. A plethora of problems may arise in the formulation, introduction and analysis of an information system use. To formulate a system, the DJP must be equipped to a greater

\footnotetext{
* Corresponding author: milla.s.setyowati@gmail.com
} 
degree with the information to be incorporated into the system. In reality, however, many of the DJP's applications contain identical information. For example, all of Apportal, SIDJP and MPN Info display information on tax payment. The only difference is that the information on the payment of Value Added Tax and Sales Tax on Luxury Goods for imported taxable services and goods is only displayed on Apportal, while supervision relies heavily on SIDJP and MPN Info. This has prevented the supervision over tax payment from being conducted optimally because external data is not integrated in the system applied.

Knowledge is managed through a set of processes, the first of which is selecting the information and knowledge to be inputed to the system. The selected knowledge is indexed and classified. This knowledge is subsequently stored within a storage which is connected to an internal network. This network will connect all people and enable them to access the knowledge, building interactions between individuals. These interactions generate new knowledge, ideas and plans that increase competitiveness between individuals in giving contributions towards the organisation's goal achievement. For this reason, the DJP created a knowledge management system named Tax Knowledge Base (TKB) accessible via Internet. TKB was created to provide education equally for all tax authorities to allow for a unified understanding when they serve the community. A unified understanding holds a great importance as it is attributed to the fair implementation of taxation regulations. TKB is managed by the Directorate of Counseling, Service and Public Relations (P2Humas), but all tax authorities can still contribute towards content creation for TKB [1].

A study on tax authorities' knowledge assumes importance as it bears a relationship with the provision of service for taxpayers and the competencies of tax authorities. The use of TKB is voluntary in nature. In other words, none of tax authorities is obliged to access it because it only serves as a repository of the tax knowledge acquired from various sources. All tax authorities may contribute towards TKB content development. Four key constructs in the Unified Theory of Acceptance and Use of Technology (UTAUT) were examined to describe TKB use by tax authorities at KPP Madya South Jakarta I. This study was aimed to analyse the effect of performance expectancy on behavioural intention, the effect of effort expectancy on behavioural intention, the effect of social influence on behavioural intention, the effect of facilitating condition on behavioural intention and the effect of behavioural intention on use behaviour.

\section{Literature review}

\subsection{Unified Theory of Acceptance and Use of Technology (UTAUT)}

Venkatesh et al. (2003) combined eight theories of technology acceptance in a number of steps. Firstly, he reviewed the similarities and differences between the constructs formed in the eight theories. Secondly, he empirically compared the eight theories with the data collected from four different organisations. Thirdly, he formulated the Unified Theory of Acceptance and Use of Technology (UTAUT). Finally, he cross-validated the UTAUT constructs against the data obtained from two new organisations [2].

The eight theories combined by Venkatesh et al. (2003) include theory of reasoned action (TRA), technology acceptance model (TAM), motivational model (MM), theory of planned behaviour (TPB), a model combining the technology acceptance model and the theory of planned behaviour (TAM+TPB), model of PC utilisation (MPCU), innovation diffusion theory (IDT) and social cognitive theory (SCT). The eight theories were subjected to separate examinations, the results of which indicate a number of disadvantages, leading to the formation of four main constructs. The disadvantages of previous theories include the following: they were concerned with simple technologies employed by individuals in an 
organisation, they conducted theoretical tests on student participants, the theoretical tests were conducted after the refusal of a technology as opposed to prior the introduction of such technology, they researched on the same technology with subjects of different experiences and they mainly examined voluntary use that indirectly generalises mandatory use. Meanwhile, the four main constructs formed are performance expectancy, effort expectancy, social influence and facilitating conditions.

The UTAUT was researched through a longitudinal field study at four different companies. Two types of use were identified from the study, namely voluntary use and mandatory use. The study was conducted gradually in some phases: after training, one month after implementation and three months after implementation. A measurement of behaviour was carried out six months after the training. The examination in the four companies is described in the table below [3].

\section{Research method}

This research analysed the attitude of tax authorities working at KPP Madya South Jakarta I in using Tax Knowledge Base. The methods used were quantitative methods. This research is descriptive in nature and was aimed to provide a description of the circumstance, condition, situation, signs and changes existing in a community. Primary data is the data directly obtained from research objects/subjects. The subjects of this research-tax authorities-were subjected to a survey. The survey was carried out by distributing questionnaires containing questions relating to Tax Knowledge Base to tax authorities. The answers given were recorded, processed and analysed. The scale used for the testing on the main constructs was a 6-point Likert scale (agree-disagree).

The population of this research consisted of tax authorities working at KPP Madya South Jakarta I. By the time this research was conducted, there were 124 incumbent tax authorities. The population of KPP Madya South Jakarta I was homogeneous, in that all of the members were tax authorities. Sample is a subset of a population that has the characteristics desired by a researcher. A sampling technique is employed to determine a sample size. There are two sampling techniques, namely probability sampling and nonprobability sampling. The technique employed in this research was the probability sampling technique. The sample of this research was drawn using the random sampling technique from the population to minimize generalisation-related errors.

Random sampling was carried out using the sampling table by Issac and Michel, and a sample size of 88 from a population of 130 was obtained at an error rate of $10 \%$. In total, there were 91 questionnaires completed and submitted. To better analyse, the authors used a significance level of 10\% from the sampling table by Isaac and Michael, and a sample of 88 was tested. There were three sample units omitted because all of them answered all of the questions with 'strongly agree'. It was assumed that the respondents did not provide answers according to the actual condition.

Primary data was obtained from the answers to the questionnaires that employed a 6point Likert scale and was analysed using the Structural Equation Model (SEM). The SEM was used as a tool to examine the constructs influencing technology acceptance [4]. Chin (1998) suggests that the SEM should be used for investigating the relationship between constructs and evaluating the model concept. [5] Anderson and Gerbing (1998) conducted a test using the SEM in two stages. In the first stage, they tested the reliability and confirmed the specific factors of the dimension. In the second stage, they verified all assumptions using the SEM [6]. This study used SEM as a tool for analysing UTAUT constructs in TKB use. SEM is a multivariate statistical model that combines factor analysis and regression analysis (correlation) with the aim of examining the relationship of constructs or variables 
in an analysis model, both between the indicator and the construct and between the constructs per se [7].

Validity test is the test of the validity of questions in a questionnaire. The Statistical Product and Service Solution programme (hereinafter SPSS) aids validity testing by comparing $r_{\text {count }}$ and $r_{\text {table. The }} r_{\text {count }}$ is seen in the correlation between questions and is compared to the $r_{\text {table }}$. [8] SmartPLS program aids an assessment in three criteria. First, convergent validity measures the correlation between individual reflection and constructs with a correlation limit value of 0.70 . Second, discriminant validity measures the correlation between one construct and another by comparing the square root of average variance extracted (AVE) with a recommended value of 0.50 [9].

Reliability test measures whether a questionnaire instrument employed is reliable. In this research, tt was conducted using the Cronbach's Alpha method, and the data was processed using SPSS and SmartPLS. In the data processing using SPSS at a scale of 0-1, an instrument is considered reliable if its value is beyond 0.601 . The measurement using SmartPLS was conducted on the composite reliability, including internal consistency and Cronbach's Alpha, which are said to be high if they score above 0.70 .

\section{Discussions}

The respondents involved in this research were all employees at KPP Madya Jakarta Selatan I. Respondents' characteristics were described by gender, education and experience. Prior to distributing the questionnaires, it was confirmed that all employees used the Tax Knowledge Base application. Questionnaires were distributed via WhatsApp Group and Broadcast to each of the employees. Completed questionnaires totaled 91. The minimum sample size of 94 was not met when an error rate of $5 \%$ was applied. Thus, the error rate used was $10 \%$, making the required minimum sample size fall to 88 . The respondents recruited in this research were classified based on gender, experience and education.

Respondents use Tax Knowledge Base more males (47 users or 53.4 percent) than females (41 users or 46.6 per cent). All female respondents completed the questionnaires. Meanwhile, only 47 out of 83 male respondents completed the questionnaires. Most users (33 respondents) had Bachelor's Degree (S1 or D4), accounting for 37.5 per cent of all users. Employees of KPP Madya Jakarta Selatan with a working experience of 11-20 years (29 respondents) made up the greatest percentage, namely 33 per cent. The description of the measurement model and variables used to analyse the questionnaire results are presented in Figure 1.

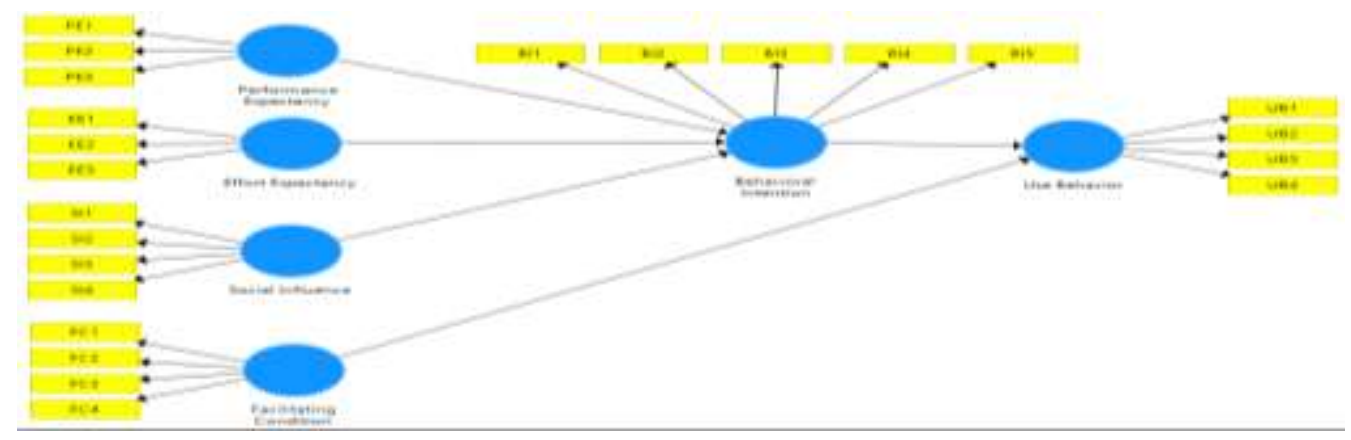

Fig. 1. TKB measurement model. 
The hypothesis testing results were obtained by conducting bootstrapping with SmartPLS at a significance level of $10 \%$ or t-table of 1.65 , and it was declared that the five hypotheses were accepted. In other words, the relationships between constructs were significant. A strong interconstruct correlation (6.433) was represented by the effect of performance expectancy on behavioural intention. A weak one (2.815) was represented by the effect of social influence on behavioural intention.

Table 1. Hypothesis testing results.

\begin{tabular}{|c|c|c|c|c|c|}
\hline Construct & $\begin{array}{c}\text { Original } \\
\text { Sample (O) }\end{array}$ & $\begin{array}{c}\text { T-statistic } \\
\text { (JO/STERR) }\end{array}$ & T-tabel & Hypothesis & Note \\
\hline PE > BI & 0.481 & 6.433 & 1.65 & $\mathrm{Ha}_{1}$ & Accepted \\
\hline EE > BI & 0.252 & 2.986 & 1.65 & $\mathrm{Ha}_{2}$ & Accepted \\
\hline SI > BI & 0.210 & 2.815 & 1.65 & $\mathrm{Ha}_{3}$ & Accepted \\
\hline FC > UB & 0.503 & 6.325 & 1.65 & $\mathrm{Ha}_{4}$ & Accepted \\
\hline BI > UB & 0.410 & 4.964 & 1.65 & $\mathrm{Ha}_{5}$ & Accepted \\
\hline
\end{tabular}

The first hypothesis stating that Performance Expectancy has an effect on Behavioural Intention was accepted with a t-statistic of 6.433. The correlation between performance expectancy and behavioural intention was strong, in which the responses 'strongly agree' and 'agree' were seen well surpassing the response 'disagree'. It can be concluded that the tax authorities at KPP Madya Jakarta Selatan found that TKB was useful, was able to speed up work and was effective for completing work. In the research by Taiwo \& Downe, the relationship between Performance Expectancy and Behavioural Intention was stronger and more significant than the relationships of other constructs [10]. This result also supports the research by Venkatesh, Morris, Davis, \& Davis (2003), Dasgupda, Haddad, Weiss, \& Bermudez (2007), and Sedana \& Wijaya (2010).

The second hypothesis stating that Effort Expectancy has an effect on Behavioural Intention was accepted with a t-statistic of 2.986. The correlation was not overly strong, which most tax authorities disagreed on the statement that TKB has comprehensive, clear, easy-to-learn and necessary information. Only 20.08 per cent of tax authorities responded 'strongly agree' to the same statement. This can be interpreted that TKB has yet to be worth using solely due to comprehensive, clear and easy-to-use contents. This result supports the research by Dasgupda, Haddad, Weiss, \& Bermudez (2007) and Sedana \& Wijaya (2010).

The third hypothesis stating that Social Influence has an effect on Behavioural Intention was accepted with a t-statistic of 2.815. According to Table 5.9, the correlation was not strong as there were 11 disagreeing responses to the statement that respondents used TKB due to the influence from colleague, superior or institution. As many as 58 respondents agreed on such statement, making up 61.65 per cent of all respondents.

The fourth hypothesis stating that Facilitating Condition has an effect on Behavioural Intention was accepted with a t-statistic of 6.325 . There was a strong direct correlation between facilitating condition and behavioural intention. Most respondents (63.35 per cent) agreed that they used TKB because it had clear information, knowledge, opportunity and guidelines. This result is supported by Venkatesh, Morris, Davis, \& Davis (2003), Dasgupda, Haddad, Weiss, \& Bermudez (2007), and Sedana \& Wijaya (2010).

The fifth hypothesis stating that Behavioural Intention has an effect on Use Behaviour was accepted with a t-statistic of 4.964. Behavioural intention strongly affected use behaviour. These figures can also be interpreted as an indirect effect of performance expectancy, effort expectancy and social influence on use behaviour. Respondents used TKB on the grounds that TKB guide was easy to understand, TKB increased their work quantity, TKB saved their working time, TKB made them more competent and TKB could serve as a guideline for them. 
In this research, the relationship between behavioral intention and use behaviour was reliable, with facilitating condition having an effect on use behaviour as found in the research by Taiwo \& Downe (2013). It was found that the direct relationship was stronger than the indirect relationship. The significance of these interconstruct relationship also support the research by Venkatesh, Morris, Davis, \& Davis (2003) and Sedana \& Wijaya (2010).

\section{Conclusion}

The first hypothesis stating that Performance Expectance has an effect on Behavioural Intention was accepted with a strong significance value. The tax authorities at KPP Madya Jakarta Selatan I found that TKB was useful, was able to speed up their work and was effective for completing their work. The second hypothesis stating that Effort Expectancy has an effect on Behavioural Intention was accepted with a fairly low significance value. Some tax authorities somewhat disagreed that TKB has comprehensive, clear, easy-to-learn and necessary content. This can be interpreted that TKB has yet to be worth using solely due to comprehensive, clear and easy-to-use content. The third hypothesis stating that Social Influence has an effect on Behavioural Intention was accepted with a fairly low significance value. Some respondents disagreed that they used TKB due to the influence of colleague, superior or institution. It is assumed that the voluntary nature of TKB use made the significance value low (Venkatesh, Morris, Davis, \& Davis, 2003). The fourth hypothesis stating that Facilitating Condition has an effect on Behavioural Intention was accepted with a strong direct correlation. Respondents agreed to use TKB because it contained clear information, knowledge, opportunity and guideline. The fifth hypothesis stating that Behavioural Intention has an effect on Use Behaviour was accepted with a strong significance value. This was indirectly influenced by performance expectancy, effort expectancy and social influence. Respondents used TKB on the grounds that TKB guideline was easy to understand, TKB increased their work quantity, TKB saved their working time, TKB made them more competent and TKB could serve as a guideline for them.

This research provides evidence that performance expectancy has a strong, direct effect on behavioural intention. Similarly, facilitating condition has a strong, direct effect on use behaviour. Therefore, we suggest that the Directorate General of Taxation should constantly try to make TKB content more interesting and easy to access. A weak correlation was present between social influence and behavioural intention. This correlation was weak because TKB use was voluntary in nature with no sanction in any form from the institution if employees did not use it. We suggest that the Directorate General of Taxation and KPP Madya Jakarta Selatan I, in particular, should encourage TKB use to prevent knowledge gap between tax authorities and to provide excellent taxation service.

\section{References}

1. D. J. Pajak, Tax Knowledge Base, Sumber Informasi Agen Kring Pajak 5002000. Retrieved September 19, 2017, from Direktorat Jenderal Pajak Kementrian Keuangan: ww.pajak.go.id/content/tax-knowledge-base-sumber-informasi-agen-kring-pajak500200, (2013)

2. V. Venkatesh, M. G. Morris, G. B. Davis, F. D. Davis. MIS Quarterly 27, 3, 425-478 (2003)

3. Jogiyanto, Sistem Informsai Keperilakuan (Andi Jogjakarta, Jogyakarta, 2007) 
4. Fatmasari, M. Ariandi, Studi Komparatif Metode UTAUT dan TAM terhadap Penerapan Sistem Informasi Akademik (Studi Kasus: Sistem Informasi Akademik Unoversitas Bina Darma Palembang) (2014)

5. J. Sarabadani, H. Jafarzadeh, M. ShamiZanjani, Toward Understanding the Determinants of Employees' E-Learning Adoption in Workplace : A Unified Theory of Acceptance and Use of Technology (UTAUT) View (2017)

6. M.-H. Wang. Advances in Management \& Applied Economics 6, 6, 63-82 (2016)

7. D. B. Ginting. Media Informatika, 12-134 (2009)

8. Y. A. Nugroho, It's Easy. Olah Data dengan SPSS (Skripta, Jogyakarta, 2011)

9. Darmawan, Pengaruh Pentingnya Sistem, Kualitas Sistem dan Kualitas Informasi terhadapKegunaan dan Kepuasan Pengguna dalam Pengembangan Sistem Informasi Manajemen Keuangan Daerah Kabupaten Sragen (Program Studi Magister Akuntasi Universitas Sebelas Maret, Surakarta, 2010)

10. A. E. Taiwo, A. G. Downe. Journal of Theoretical and Applied Information Technology, 48-58 (2013) 